WSRC-TR-2002-00391, Rev. 0

Keywords: Waste processing, cesium Retention: Permanent

\title{
ORGANIC COMPOUNDS IN SAVANNAH RIVER SITE HIGH-LEVEL WASTE
}

D. D. Walker

September 30, 2002

Westinghouse Savannah River Company

Savannah River Technology Center

Aiken, SC 29808

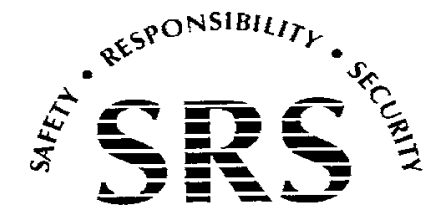

SAVANNAHRIVER SITE 
This document was prepared in conjunction with work accomplished under Contract No. DE-AC09-96SR18500 with the U. S. Department of Energy.

\section{DISCLAIMER}

This report was prepared as an account of work sponsored by an agency of the United States Government. Neither the United States Government nor any agency thereof, nor any of their employees, makes any warranty, express or implied, or assumes any legal liability or responsibility for the accuracy, completeness, or usefulness of any information, apparatus, product or process disclosed, or represents that its use would not infringe privately owned rights. Reference herein to any specific commercial product, process or service by trade name, trademark, manufacturer, or otherwise does not necessarily constitute or imply its endorsement, recommendation, or favoring by the United States Government or any agency thereof. The views and opinions of authors expressed herein do not necessarily state or reflect those of the United States Government or any agency thereof.

This report has been reproduced directly from the best available copy.

Available for sale to the public, in paper, from: U.S. Department of Commerce, National Technical Information Service, 5285 Port Royal Road, Springfield, VA 22161, phone: (800) 553-6847, fax: (703) 605-6900

email: orders@ntis.fedworld.gov

online ordering: http://www.ntis.gov/help/index.asp

Available electronically at http://www.osti.gov/bridge

Available for a processing fee to U.S. Department of Energy and its contractors, in paper, from: U.S. Department of Energy, Office of Scientific and Technical Information, P.O. Box 62, Oak Ridge, TN 37831-0062,

phone: (865)576-8401,

fax: (865)576-5728

email: $\underline{\text { reports@ adonis.osti.gov }}$ 
WSRC-TR-2002-00391, Rev. 0

Page 2 of 25

REVIEWS AND APPROVALS

Author

Darrel D. Walker

$9130 / 02$

D. D. Walker

Date

Waste Processing Technology

Technical Review

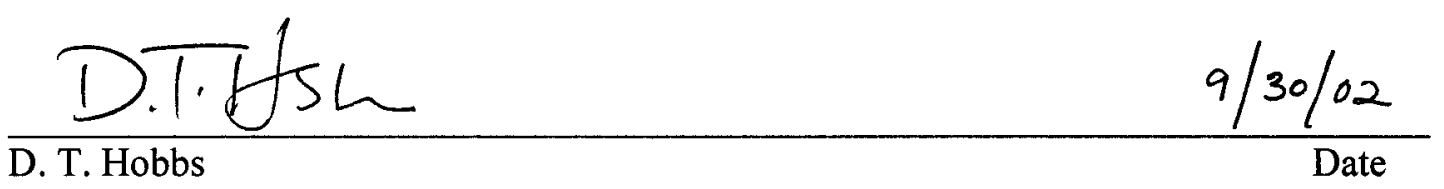

Waste Processing Technology

Approvals
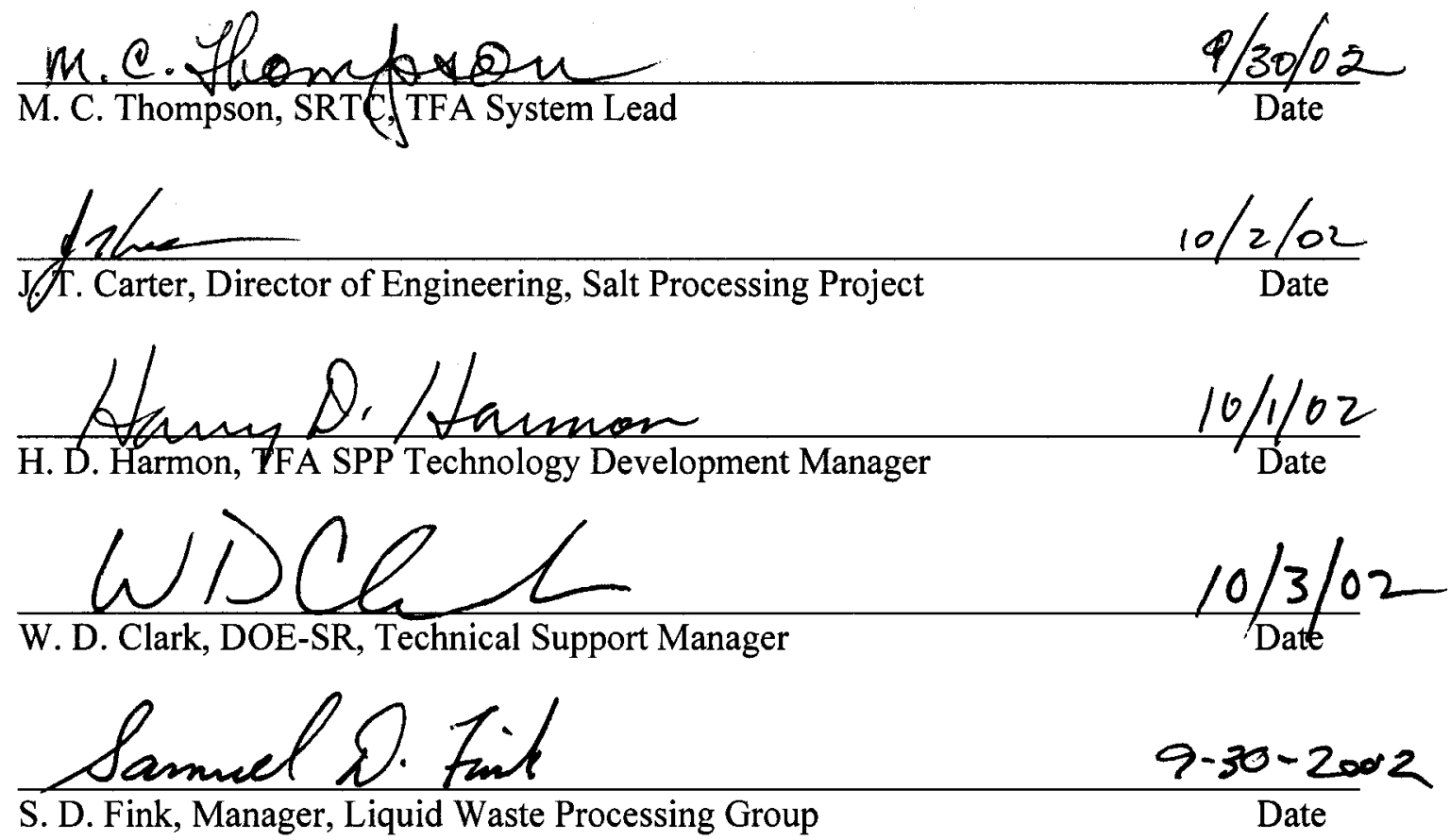

$\frac{\text { Omens } C \text {. When for W LT }}{10 / 3 / 02}$ 


\section{CONTENTS}

SUMMARY

INTRODUCTION

RESULTS AND DISCUSSION........................................... 7

Results from the Tank Farm Samples............................... 7

Process Chemicals from Canyon..................................... 8

Cleaning Chemicals for Equipment Decontamination............... 12

SRTC and Analytical Laboratories Waste.......................... 13

Chemicals from Tank Farm Operations........................... 12

Other Sources...................................................... 16

CONCLUSIONS....................................................................................... 18

FUTURE WORK......................................................................... 19

ACKNOWLEDGMENTS.................................................. 19

APPENDIX A....................................................... 20

REFERENCES........................................................... 23

\section{LIST OF FIGURES}

1 Structures of Ion Exchange Resins.............................. 11

2 Potential Structures of Fragments Formed from Ion Exchange

Resins ................................................................ 11

$3 \quad$ Structure of Gluconic Acid........................................ 12

$4 \quad$ General Structure of Alkyl Aryl Sulfonates...................... 12

5 Structure of Polydimethylsilanols and Polydimethylsilanolates... 15

\section{LIST OF TABLES}

I Organic Compounds Found in SRS Tank Farm Samples........ 7

II Canyon Solvent Losses......................................... 9

III Types of Ion Exchange Resins Used in Canyon Operations...... 10

IV Ion Exchange Resins Sent to Tank Farms........................ 10

$V \quad$ Cleaning Agents Used in Equipment Decontamination............ 13

VI Organic Compounds from the In-Tank Precipitation Process.... 14

VII Organic Chemicals Used in the DWPF Laboratory.............. 15

VIII Organic Compounds in the DWPF Cold Run-In Waste.......... 16

IX Organic Compounds Found in or Sent to SRS Tank Farms that May Affect CSSX Processing................................... 18 


\title{
ORGANIC COMPOUNDS IN SAVANNAH RIVER SITE HIGH- LEVEL RADIOACTIVE WASTE
}

\author{
D. D. Walker
}

\section{SUMMARY}

The Savannah River Site (SRS) tank farms contain the accumulated high-level radioactive waste from almost 50 years of site operations. This document summarizes information from waste analyses and chemical usage records related to organic compounds that have been sent to the tank farms. Information on potential decomposition products from the original organic compounds is also included. This information is pertinent to the caustic side solvent extraction (CSSX) process planned for decontaminating the liquid waste before disposal in Saltstone. Certain classes of organic compounds can interfere with the extraction process. The following conclusions result from the review.

- Organic compounds that can interfere with the solvent extraction process are present, have been sent, or are currently used in the tank farm.

- Examples of interfering compounds identified in this study include the following.

- Tributylphosphate (extractant used in F and H Canyons) and its hydrolysis product, dibutylphosphate.

- Siloxanes and siloxanols (breakdown products from defoaming agents)

- Ion exchange resin fragments

- Alkyl-aryl sulfonates (found in soaps, detergents, surfactants and certain process chemicals)

- With present information, it is not possible to determine the concentration (and therefore, the potential threat to the CSSX process) of the interfering compounds. A parallel study a Pacific Northwest National Laboratory (PNNL) involves analysis of samples from selected tanks to determine the concentration of organic compounds in waste samples.

Recommendations for additional work include a more thorough effort in searching available records related to chemical use and disposal, deployment of analytical methods for determining concentrations of compounds of interest, and a program of sampling and analysis. 


\section{INTRODUCTION}

The SRS high-level waste tank farms store and process high-level liquid waste from a number of sources, including F- and H-Canyons, Receiving Basin for Off site Fuels (RBOF), the 299-H Decontamination Facility, Savannah River Technology Center, site analytical laboratories, and the Defense Waste Processing Facility (DWPF). The waste has been extensively analyzed for inorganic components and a data base containing the composition of the waste in each tank exists. ${ }^{1}$ However, few analyses of organic compounds in waste have been obtained, largely because very little organic waste is sent to the tank farm and because, historically, SRS capabilities in this area have been limited.

The present study identifies organic compounds or classes of compounds that may occur in SRS high-level waste (HLW) based on a review of previous sample analyses and records of disposals of organic compounds to the HLW tank farms. Although in some cases the amounts of compounds sent to the tank farms are known and are included here, in general this report only seeks to identify compounds that may be present. Where possible, the chemical or radiolytic decomposition products from the initial compounds are identified.

This study was undertaken because certain categories of organic compounds can interfere with the caustic-side solvent extraction (CSSX) process proposed for decontamination of soluble high-level waste at the SRS. In 2001, the Department of Energy selected the CSSX process for removal of cesium from alkaline waste solutions prior to disposal in Saltstone. $^{2}$ Knowledge of the presence and concentrations of interfering compounds in SRS soluble waste is needed to ensure good process performance.

Recently, researchers at Pacific Northwest National Laboratory (PNNL) began development of analytical methods for several classes of organic compounds. The methods are suitable for high-level radioactive waste and the program includes analysis of several waste samples from the SRS. ${ }^{3}$ Early results from the study documented in this report identified the classes of compounds for which the PNNL researchers developed methods.

\section{Categories of Organic Compounds that may Interfere with Solvent Extraction}

Compounds that are known or expected to interfere with the CSSX process are characterized by the presence of a polar (ionic or neutral) end and a non-polar (aliphatic or aromatic) end. Usually, these compounds interfere by accumulating in the solvent, thereby affecting extraction or stripping of cesium. Small, polar or ionic organic molecules with appreciable water solubility tend not to interfere because they are purged in the aqueous process streams (e.g., they remain in the alkaline waste, or are removed from the solvent by the acidic strip or alkaline wash solutions). Lipophilic molecules containing large paraffinic or aromatic portions exhibit low solubility in water and high solubility in the CSSX solvent. The division between "small molecules" and "large molecules" occurs at 8 to 12 paraffinic or aromatic carbon atoms. ${ }^{4}$ 
The following sections describe examples of known or suspected compounds that interfere with the CSSX process.

\section{Soaps and detergents}

These compounds contain anionic head groups (typically sulfonates or carboxylates) with large, non-polar tails (either paraffinic, aromatic, or a combination). Examples include dodecylsulfonate ${ }^{5}$ and dimethylnapthalenesulfonate ${ }^{6}$ which are known to interfere in CSSX stripping. Cleaning and decontaminating agents based on polyethylene glycols or chelating agents such as ethylenediaminetetraacetic acid (EDTA) and related compounds are likely too water soluble to accumulate in the solvent.

\section{Phosphates}

Alkyl phosphates with 12 or more carbon atoms can build up in the solvent. They interact with the modifier (trioctylamine), reducing its ability to solvate anions needed for charge balance with the cationic extractant-cesium complex. Tributyl phosphate (TBP) typifies this category (12 carbons). Dibutylphosphate ( 8 carbons) also interferes with stripping, ${ }^{4}$ but monobutylphosphate is likely too water soluble to accumulate in the solvent.

\section{Alcohols}

Alcohols with long aliphatic or aromatic chains may affect the CSSX process. Short chain homologs, such as methanol, ethanol, isopropanol, and butanol are too water soluble to build up in the solvent.

\section{Amines}

Amines with intermediate length alkyl groups may extract from the alkaline waste into the solvent as neutral molecules. Protonation in the acidic scrub stages allows extraction of the alkylammonium ion into the aqueous phase. The aqueous scrub stream returns to the last extraction stage where it combines with the alkaline waste. Deprotonation by the waste allows extraction to repeat, sending the amine back to the scrub section. This feedback loop could produce high amine concentrations. Trimethylamine is an example of this class. Amines with longer alkyl chains show higher solubility in the solvent and are unlikely to participate in the feed-back loop, but could accumulate in the solvent. Tri- $n$ octylamine, a component of the solvent system, remains in the solvent and exemplifies the behavior of this class of compounds with longer alkyl chains. 


\section{RESULTS AND DISCUSSION}

\section{Results from Tank Farm Samples}

Starting in 1998, a Potential Inadequacy in the Safety Analysis (PISA) related to flammability concerns in SRS waste tanks ${ }^{7}$ resulted in a program to sample and analyze SRS waste for volatile and semivolatile organic compounds. The program identified several organic compounds in the vapor space and waste. ${ }^{8}$ Table I lists the results of this program.

TABLE I. Organic Compounds Found in SRS Tank Farms

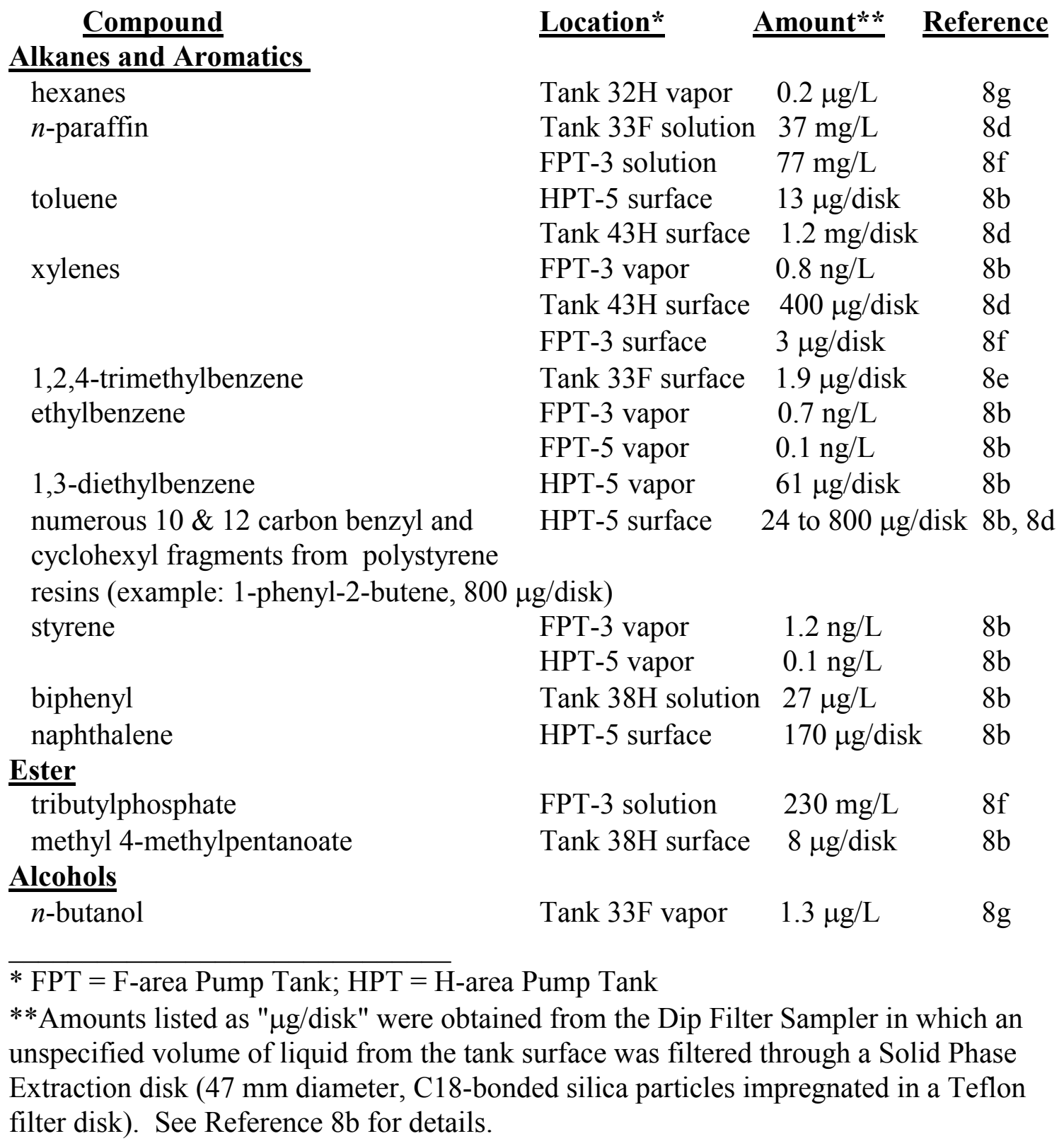


TABLE I. Organic Compounds Found in SRS Tank Farms (continued)

\section{Compound \\ Organic Acid Anions}

formate

\section{Aldehydes and Ketones}

acetone

2-butanone

4-methyl-2-pentanone

hexanal

Miscellaneous Other

4,4-oxybisbenzenamine

Siloxanes

hexamethyl disiloxane

methoxytrimethylsiloxane

trimethyl silanol

methoxytrimethyl silane

\begin{tabular}{llll} 
Location* & \multicolumn{1}{l}{ Amount** } & & Reference \\
\cline { 2 - 2 } Tank 33F solution & $1.3 \mathrm{~g} / \mathrm{L}$ & & $8 \mathrm{~d}$ \\
FPT-3 solution & $2.6 \mathrm{~g} / \mathrm{L}$ & $8 \mathrm{f}$ \\
& & \\
FPT-3 vapor & $1.4 \mathrm{ng} / \mathrm{L}$ & $8 \mathrm{~b}$ \\
FPT-3 vapor & $0.6 \mathrm{ng} / \mathrm{L}$ & $8 \mathrm{~b}$ \\
FPT-5 vapor & $0.5 \mathrm{ng} / \mathrm{L}$ & $8 \mathrm{~b}$ \\
FPT-3 vapor & $1.4 \mathrm{ng} / \mathrm{L}$ & $8 \mathrm{~b}$ \\
HPT-5 surface & $35 \mu \mathrm{g} / \mathrm{disk}$ & $8 \mathrm{~b}$ \\
& & \\
Tank 38H solution & $1 \mathrm{mg} / \mathrm{L}$ & $8 \mathrm{~b}$ \\
& & \\
Tank 38H surface & $280 \mu \mathrm{g} / \mathrm{disk}$ & $8 \mathrm{~b}$ \\
Tank 26F surface & $52 \mu \mathrm{g} / \mathrm{disk}$ & $8 \mathrm{e}$ \\
Tank 33F surface & $44 \mu \mathrm{g} / \mathrm{disk}$ & $8 \mathrm{e}$ \\
FPT-3 surface & $260 \mu \mathrm{g} / \mathrm{disk}$ & $8 \mathrm{~b}$ \\
Tank 38H surface & $87 \mu \mathrm{g} / \mathrm{disk}$ & $8 \mathrm{~b}$ \\
Tank 38H surface & $31 \mu \mathrm{g} / \mathrm{disk}$ & $8 \mathrm{~b}$ \\
Tank 26F surface & $50 \mu \mathrm{g} / \mathrm{disk}$ & $8 \mathrm{e}$ \\
Tank 33F surface & $95 \mu \mathrm{g} / \mathrm{disk}$ & $8 \mathrm{e}$ \\
FPT-3 surface & $150 \mu \mathrm{g} / \mathrm{disk}$ & $8 \mathrm{~b}$ \\
Tank 26F surface & $110 \mu \mathrm{g} / \mathrm{disk}$ & $8 \mathrm{e}$ \\
Tank 33F surface & $270 \mu \mathrm{g} / \mathrm{disk}$ & $8 \mathrm{e}$ \\
FPT-3 surface & $160 \mu \mathrm{g} / \mathrm{disk}$ & $8 \mathrm{~b}$ \\
& &
\end{tabular}

* FPT $=$ F-area Pump Tank; HPT $=$ H-area Pump Tank

** Amounts listed as " $\mu \mathrm{g} /$ disk" were obtained from the Dip Filter Sampler in which an unspecified volume of liquid from the tank surface was filtered through a Solid Phase Extraction disk (47 mm diameter, C18-bonded silica particles impregnated in a Teflon filter disk). See Reference $8 b$ for details.

\section{Process Chemicals from Canyons}

The HLW at the SRS came from processing of nuclear materials by solvent extraction, ion exchange, and precipitation processes. Solvent extraction used tributyl phosphate (TBP) extractant dissolved in a paraffinic solvent. The original paraffinic solvent, called Ultrasene, contained branched chains and aromatic components. $n$-Paraffin containing 12- to 16-carbon chains replaced Ultrasene. Ion exchange processing used both anion and cation exchange resins. Head end operations for fuel dissolution used gelatin and gluconic acid. In addition, cleaning agents used in the canyons may also occur in waste sent to the tank farms. 


\section{Solvent Losses}

Solvent (TBP and $n$-paraffin) may reach the tank farms dissolved or entrained in the aqueous waste stream. Canyon evaporators volatilize most of the $n$-paraffin and steam strip some of the TBP before transfer to the tank farms. ${ }^{9}$ Requirements on waste generators limit second (organic) phase transfers to less then 0.5 volume $\% .{ }^{10}$ However, quarterly flushes of the evaporators to remove potential buildup of "red oil" sends some solvent directly to the tank farms. In addition, there have been occasional inadvertent transfers of larger amounts. ${ }^{11}$ Table II lists estimated average annual losses for the entire 38-year operating life (1954 to 1992) based on entrainment of solvent in the aqueous process streams. ${ }^{12}$ In 1984 , M. C. H. Fong estimated significantly lower annual losses for 1954 to 1984 based on fresh solvent additions to the canyons over the previous few years (Appendix A). She estimated only $15 \%$ of the F Canyon and 3.4\% of the $\mathrm{H}$ Canyon values shown in Table II. Based on modeling of evaporation of organic liquids, any $n$ paraffin that reaches the tank farm persists for only a few months due to the low burden and continuous tank ventilation. ${ }^{13}$

TBP that reaches the tank farm slowly hydrolyzes in the aqueous alkaline waste by the following reaction sequence. ${ }^{14}$

$$
\begin{aligned}
& \left(\mathrm{C}_{4} \mathrm{H}_{9} \mathrm{O}\right)_{3} \mathrm{PO}+\mathrm{OH}^{-}=>\left(\mathrm{C}_{4} \mathrm{H}_{9} \mathrm{O}\right)_{2} \mathrm{PO}_{2}^{-}+\mathrm{C}_{4} \mathrm{H}_{9} \mathrm{OH} \\
& \text { TBP DBP } n-\mathrm{BuOH} \\
& \underset{\mathrm{DBP}}{\left(\mathrm{C}_{4} \mathrm{H}_{9} \mathrm{O}\right)_{2} \mathrm{PO}_{2}^{-}}+\mathrm{OH}^{-}=\underset{\mathrm{MBP}}{\left(\mathrm{C}_{4} \mathrm{H}_{9} \mathrm{O}\right) \mathrm{PO}_{3}{ }^{2-}}+\underset{n-\mathrm{BuOH}}{\mathrm{C}_{4} \mathrm{H}_{9} \mathrm{OH}} \\
& \underset{\mathrm{MBP}}{\left(\mathrm{C}_{4} \mathrm{H}_{9} \mathrm{O}\right) \mathrm{PO}_{3}{ }^{2-}+\mathrm{OH}^{-} \Rightarrow} \quad \mathrm{PO}_{4}^{{ }^{3-}-}+\underset{n-\mathrm{BuOH}}{\mathrm{C}_{4} \mathrm{H}_{9} \mathrm{OH}}
\end{aligned}
$$

In addition, radiolytic degradation of paraffins during canyon processing produces primary carboxylic acids with 12 to 16 carbons and secondary carboxylic acids with 8 to 10 carbons. These non-volatile compounds are likely soluble in the alkaline waste.

TBP, $n$ - $\mathrm{BuOH}$, and $n$-paraffin have been reported in tank farm samples (Table I). Interestingly, the TBP was found in an F-area pump tank sample (e.g., in waste on its way to the tank farm) but not in actual waste samples, suggesting that hydrolysis may prevent

\section{TABLE II. Canyon Solvent Losses}

\begin{tabular}{|c|c|}
\hline \multicolumn{2}{|c|}{ Amount (gal/yr) } \\
\hline F Canyon & H Canyon \\
\hline 13,613 & 7,005 \\
\hline 8,880 & 2,182 \\
\hline
\end{tabular}

\section{Component $n$-paraffin \\ TBP}


significant accumulation in the waste tanks. Analyses for DBP did not reveal amounts above the relatively high detection limits $(300$ to $3000 \mathrm{mg} / \mathrm{L})$. No analytical method was available for MBP.

\section{Ion Exchange Resins}

Canyon and B-line processes use both anion and cation exchange resins. These include the F Canyon Primary Recovery Column for recovery of Pu and $\mathrm{Np}$ (anion), H-Canyon frames for decontaminating and separating $\mathrm{Pu}$ and $\mathrm{Np}$ (anion), $\mathrm{HB}$ line for final $\mathrm{Np}$ purification (anion), F Canyon thorium removal column (cation), and FB line for concentration of $\mathrm{Pu}$ (cation). FB line cation resin goes to solid waste, but the others go to the tank farms. Relatively small amounts of the resin for thorium recovery have been used. Table III lists the types of ion exchange resins used in canyon operations and Figure 1 shows their structures. Most resins contained polymeric backbones made of polystyrene or styrene-divinylbenzene copolymer. Anion resins typically contained a quaternary amine functional group, although some contained a methylpyridinium group. Table IV lists the amounts of resins sent to the tank farms (Appendix A).

The majority of the resins were digested ${ }^{15}$ in alkaline permanganate before going to tank farms, although about $15 \%$ was sent undigested due to problems associated with the digestion process. Permanganate digestion breaks down the resins to short chains that

\section{TABLE III. Types of Ion Exchange Resins Used in Canyon Operations}

\section{$\underline{\text { Resin type }}$}

Anion

Polystyrene gel

Dowex 1-X2

Dowex 1-X3

Styrene-divinylbenzene macroporous

Dowex MSA-1

Dowex $21 \mathrm{~K}$

Ionac A-641

Cation

Styrene-divinylbenzene

Dowex 50W thorium removal and $\mathrm{Pu}$ concentration

\section{Application}

1960-74, all separations columns

1975-95, all separations columns

thorium removal and Pu concentration

\section{TABLE IV. Ion Exchange Resins Sent to Tank Farms}

\section{$\underline{\text { Resin Type }}$}

Anion, polystyrene, gel-type

Anion, styrene-divinylbenzene

Cation (Dowex 50W)

\section{Amount (L)}

$\underline{\text { F Area }} \quad \underline{\text { H Area }}$

$18,000 \quad 26,000$

$25,000 \quad 55,000$

Unknown 0 
Polystyrene:

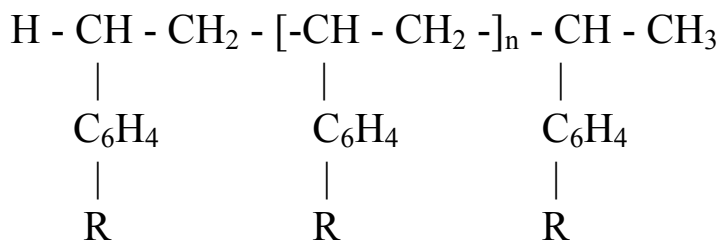

Styrene-Divinylbenzene

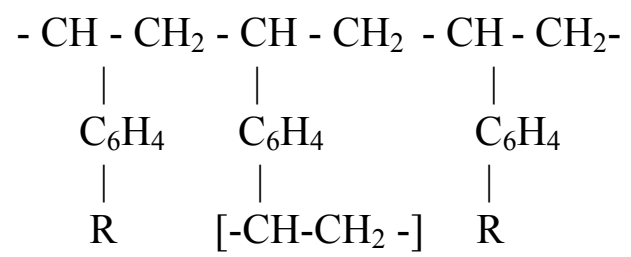

where $-\mathrm{C}_{6} \mathrm{H}_{4^{-}}=$di-substituted phenyl group

$\mathrm{R}=$ Anion resins $-\mathrm{N}\left(\mathrm{CH}_{3}\right)_{3}{ }^{+}$or $-\mathrm{C}_{5} \mathrm{H}_{4} \mathrm{~N}\left(\mathrm{CH}_{3}\right)^{+}$

Cation resins $-\mathrm{C}_{6} \mathrm{H}_{5} \mathrm{SO}_{3}^{-}$

FIGURE 1. Structures of Ion Exchange Resins

contain alcohol and carboxylic acid groups. Depending on the length of the chain, the resulting fragments may be soluble in aqueous solution. Radiolysis will also contribute to the breakdown of the resins, eventually forming small organic molecules, hydrogen, carbon dioxide, and ammonia. Trimethylamine (TMA) forms from the quaternary amine functional groups. TMA and other volatile organic compounds occur occasionally in vapor samples taken from tank exhaust systems. ${ }^{16}$ Figure 2 shows potential non-volatile fragments and TMA formed from these processes.

\section{Other Chemicals}

In a few campaigns during the early 1950 's, canyon operators added gluconic acid to solubilize head-end cake rather than transfer solid/liquid slurries. Gluconic acid (Figure 3) radiolytically decomposes to carbon dioxide and water. ${ }^{17}$ It is unlikely that any remains in the high- level waste.

Alcohol fragments :

Carboxylic acid fragments:

Aliphatic tertiary amines:
$\mathrm{R}-\mathrm{C}_{6} \mathrm{H}_{4}-\mathrm{CH}_{2}-\mathrm{OH}$

$\mathrm{R}-\mathrm{C}_{6} \mathrm{H}_{4}-\mathrm{COOH}$

$\mathrm{N}\left(\mathrm{CH}_{3}\right)_{3}$

FIGURE 2. Potential Structures of Fragments Formed from Ion Exchange Resins 


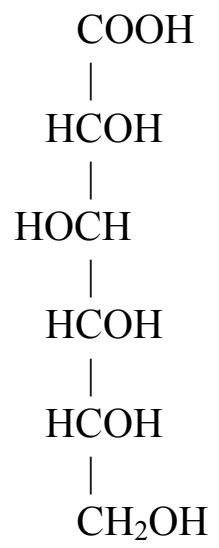

FIGURE 3. Structure of Gluconic Acid

Starting in the late 1950 's, operators added gelatin as a flocculating agent to remove silica from nitric acid solutions of dissolved nuclear fuels. ${ }^{18}$ Gelatin, a protein, is a polymer of amino acids, primarily glycine, proline, and hydroxyproline. Proteins undergo rapid hydrolysis in strongly alkaline solutions, yielding the individual amino acids. Radiolysis will eventually reduce the amino acids to ammonia, carbon dioxide, and water.

The anionic powdered detergent Alconox ${ }^{\circledR}$, made by Alconox, Inc., White Plains, New York, contains alkyl aryl sulfonates. ${ }^{19}$ Figure 4 shows the general structure. This structure appears relatively stable to radiation and may exist for years in tank farm waste. Compounds of this general structure interfere with stripping in the CSSX process. ${ }^{5}$

\section{Cleaning Chemicals from Equipment Decontamination}

Decontamination of equipment in Building 299-H results in transfers of miscellaneous organic wastes to the tank farm. This includes decontamination chemicals, oils and greases, and gasoline from the $299-\mathrm{H}$ waste collection tank. Although oxalic and nitric acid are most commonly used for decontamination, agents containing organic chemicals have also been used. Table V lists some of the cleaning agents used in the past few years. Cleaning

$$
\begin{array}{ll}
\mathrm{R}-\mathrm{Ar}-\mathrm{SO}_{3} \mathrm{H} & \text { where } \mathrm{R}=\text { alkyl chains } \\
\mathrm{Ar}=\text { phenyl or naphthyl groups }
\end{array}
$$

FIGURE 4. General Structure of Alkyl Aryl Sulfonates 
TABLE V. Cleaning Agents Used in Equipment Decontamination

$\begin{array}{ll}\underline{\text { Agent }} & \text { Organic Components } \\ \text { SC-200 } & \text { 2-butoxyethanol } \\ \text { Versene } & \text { EDTA } \\ \text { Turco 4324 NP } & \text { EDTA } \\ \text { Alconox } & \text { alkyl aryl sulfonates }\end{array}$

agents containing EDTA are not currently recommended for use in this facility. With the exception of Alconox ${ }^{\circledR}$, these compounds are not expected to interfere with the solvent extraction process.

\section{SRTC and Analytical Laboratories Waste}

Laboratory facilities use a wide variety of organic chemicals, although most are used in small amounts. Aqueous radioactive waste containing these chemicals eventually transfers to the tank farms. In SRTC, aqueous waste sent to the High and Low Activity Drain systems is trucked to F Area (Building 211-F) where it is evaporated before transfer to the tank farm. Waste disposal procedures in the laboratories limit the amount of organic compounds disposed to the drains by requiring that all chemicals be water soluble. In addition, evaporative concentration of the waste in F Area will remove volatile organic compounds. For these reasons, SRTC and Analytical Laboratories likely do not contribute significant amounts of organic compounds to tank farm waste.

Scintillation cocktails used in radioactivity counting methods represent a possible exception to this argument. Since the early 1990's, scintillation cocktails made from mixtures of water soluble chemicals have been routinely sent to the high activity drain system in SRTC. Analytical Laboratories and Bioassay use similar scintillation cocktails. Packard Instruments Ultima Gold ${ }^{\mathrm{TM}}$, a typical scintillation cocktail used at SRS, contains bis(1-methylethyl)naphthalene (65-70\%) and a detergent, bis(2-ethylhexyl)hydrogen phosphate $(9-12 \%)$ as the major ingredients. ${ }^{20}$ Dr. David DiPrete of SRTC estimated the annual SRTC usage rate is 25-35 gallons per year. These two compounds would likely be scavenged by the CSSX solvent and the detergent could interfere with cesium stripping.

\section{Chemicals from Tank Farm Operations}

\section{Corrosion inhibition}

Sodium nitrite and sodium hydroxide are used to inhibit corrosion in the carbon steel waste tanks. Waste management personnel add these chemicals directly to the tanks and to "inhibited" water used in the tank farms. Site facilities also add these inhibitors to wastes prior to transferring into the tank farms. Since at least 1997, various SRS facilities (DWPF and F- and H Canyons) have purchased and used Repauno "Super Free Flowing" 
technical grade sodium nitrite containing $0.05 \mathrm{wt} \%$ Petro AG. Petro AG is an alkylated naphthalene sulfonate salt added to the sodium nitrite as an anti-clumping agent. It is known to interfere with solvent extraction processing. ${ }^{5}$

\section{In-Tank Precipitation Process (ITP): Tanks 48H, 49H, and 50H}

In 1982 and 1995, SRS personnel decontaminated large batches of high-level waste in Tank $48 \mathrm{H}$ using tetraphenylborate to precipitate cesium. The decontaminated salt solution from both campaigns was sent to Tank $50 \mathrm{H}$. The waste water from the 1982 campaign was stored in Tank 49H. In 2001-2002, the remaining phenylborates in Tank $49 \mathrm{H}$ were intentionally decomposed and the waste transferred to Tank $50 \mathrm{H}$. The heel left after transferring the waste contained a small amount of sodium tetraphenylborate and phenol. At this time, Tank $48 \mathrm{H}$ continues to store tetraphenylborate waste, although methods for returning this tank to normal service are under study. Table VI lists the known organic compounds in Tank $48 \mathrm{H}$ and $49 \mathrm{H}$. All solutions transferred to Tank $50 \mathrm{H}$ have or will be removed from the tank farm and sent to Saltstone. ${ }^{21}$

\section{Evaporators}

Waste management personnel use siloxane defoamers to prevent or minimize foaming in the tank farm evaporators. These are polydimethylsiloxane (PDMS) based, but may include minor amounts of other organics such as methylcellulose, methylated silica, mono- and di-glycerides (C14 to C18), and hydrogenated tallow glycerides. The PDSM chains vary in molecular weight between 5,000 and 10,000 g/mole. Dow Corning $\mathrm{H}-10$ and Dow Corning Antifoam $\mathrm{B}$ have been used in the $2 \mathrm{~F}$ and $2 \mathrm{H}$ evaporators.

\section{TABLE VI. Organic Compounds from the In-Tank Precipitation Process*}

Compound

$\underline{\text { Soluble }}$

Sodium tetraphenylborate

Phenol

Insoluble

Biphenyl

Terphenyl isomers

Tetraphenylborate

(present as $\mathrm{K}$ and Na salts) $\quad 25,000$

\section{Amount (kg)}

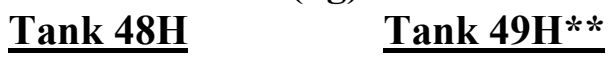

$<15$

0.4

830

24

Unknown Unknown

Unknown Unknown

None

*This list does not contain insoluble potassium and cesium tetraphenylborates.

** Estimated assuming a 10,000 gal heel and concentrations listed in reference. ${ }^{22}$ 
PDMSs decompose from radiolysis and alkaline hydrolysis. Radiation results in crosslinking of PDMS molecules. Hydrolysis results in polydimethylsilanolates. Figure 5 shows the structures of PDMSs and silanolates.

\section{DWPF}

DWPF personnel use small amounts of organic chemicals in the analytical laboratory and organic defoaming agents in the Sludge Receipt Adjustment Tank (SRAT). Table VII lists chemicals used in the analytical laboratory. DWPF personnel used Dow Corning 544 defoamer (PDMS based) in the past and currently use IIT-747 (containing polyethermodifed PDMS copolymers, polyether-modified heptamethyltrisiloxane, and allyloxypolyethyleneglycol methylether). The contents of the SRAT are sent to the DWPF melter where they likely decompose. Semivolatile decomposition products could be scrubbed in the DWPF off gas system and transferred to the tank farm in the DWPF recycle stream. However, the amounts reaching the tank farm are likely insignificant.

During startup of the DWPF in 1995, approximately 140,000 gallons of "Coupled Feed Cold Runs" Recycle transferred by truck to Tank $22 \mathrm{H}$. This waste resulted from cold chemical tests of tetraphenylborate decomposition by the acid hydrolysis process. The waste produced was not analyzed for organic compounds, but a waste compliance plan indicated the compounds listed in Table VIII would be present.
A: $\quad\left(\mathrm{CH}_{3}\right)_{3} \mathrm{Si}-\mathrm{O}-\mathrm{Si}\left(\mathrm{CH}_{3}\right)_{\mathrm{n}}-\mathrm{O}-\mathrm{Si}\left(\mathrm{CH}_{3}\right)_{3}$
B: $\quad\left(\mathrm{CH}_{3}\right)_{3} \mathrm{Si}-\mathrm{O}-\mathrm{Si}\left(\mathrm{CH}_{3}\right)_{\mathrm{n}}-\mathrm{O}-\mathrm{Si}\left(\mathrm{CH}_{3}\right)_{2}-\mathrm{OH}$
or
B: $\quad \mathrm{HO}-\mathrm{Si}\left(\mathrm{CH}_{3}\right)_{2}-\mathrm{O}-\mathrm{Si}\left(\mathrm{CH}_{3}\right)_{\mathrm{n}}-\mathrm{O}-\mathrm{Si}\left(\mathrm{CH}_{3}\right)_{2}-\mathrm{OH}$

\section{FIGURE 5. Structure of Polydimethylsilanols (A) and Polydimethylsilanolates (B)}

TABLE VII. Organic Chemicals Used in the DWPF Laboratory
$\begin{array}{lc}\text { Compound } & \text { Usage Rate (g/yr) } \\ \text { succinic acid and disodium succinate } & 82 \\ \text { di- and trisodium cyclohexanediaminetetraacetate } & 46 \\ \text { EDTA } & 18 \\ \text { [ethylenebis(oxyethylenenitrilo)]-tetraacetic acid } & 2 \\ \text { methanol } & \text { Unknown } \\ \text { formic acid } & \text { Unknown } \\ \text { oxalic acid }^{\circledR} & \text { Unknown } \\ \text { Alconox } & \text { Unknown }\end{array}$


TABLE VIII. Organic Compounds in the DWPF Cold Run-In Waste

\section{Compound}

Benzene

Aniline

Nitrobenzene

Sodium phenoxide

Sodium 2- and 4-nitrophenoxide

Sodium 4-nitrosophenoxide

Sodium 2,4-dinitrophenoxide

Sodium 2- and 4-phenylphenoxide

Sodium 4-phenylazophenoxide

Dow Corning 544

Quinone

Biphenyl

o-, m-, and p-terphenyl

Diphenylamine

Triphenylamine

2- and 4-Nitrodiphenylamine

N-Phenylformamide

Diphenylformamide

Carbazole

3H-phenoxazin-3-one

\section{Amount (kg)*}

0.5

20

0.1

50

70

200

$<0.3$

$<0.5$

3

8

0.5

2

2

2

0.5

$<1$

$<3$

0.5

$<0.5$

0.5

*Based on 140,000 gal of waste and concentrations listed in reference. ${ }^{23}$

\section{Future Tank Farm Operations}

Plans for future tank operations include using monosodium titanate (MST) to remove strontium and actinides from waste prior to cesium removal. MST typically contains small amounts of methanol and isopropanol whose combined concentration is limited to $500 \mathrm{ppm}$ by the purchase specifications. ${ }^{24}$ Based on current projected usage rates $(0.4 \mathrm{~g}$ $\mathrm{MST} / \mathrm{L}$ of waste), the filtrate stream from the MST process going to the CSSX process will contain approximately $1.5 \mathrm{mg}$ of methanol and isopropanol per liter of waste solution.

\section{Other Sources}

\section{Ion Exchange Resins from RBOF}

RBOF cleans and regenerates mixed bed ion exchange resins from the reactor cooling basins. This process includes removing fines and sorbed materials and sending them to the $\mathrm{H}$ Area tank farm (Tanks $21 \mathrm{H}, 22 \mathrm{H}$, and $23 \mathrm{H})$. Normally, the waste transfers contain 
only small amounts of resin particles, but occasional equipment failures result in transfer of larger quantities of resin. A mixed bed ion exchange column contains both cation and anion resins. RBOF typically uses Amberlite IR-120 (cation) and Amberlite IR-400-1 (anion) resins. Both are styrene-divinylbenzene copolymers, containing either sulfonated benzene rings (cation) or quaternary amines (anion) as functional groups. Estimated amounts transferred to the tank farm are less than amounts added from the canyon and Bline processes. ${ }^{15 \mathrm{~b}}$

\section{Coal}

In 1970, three separate backwashings of the K Area sand filter were sent to Tank $7 \mathrm{~F}^{25}$ Some sand and coal was inadvertently included in the third backwash. The total is unknown, but only a small fraction of the $17,000 \mathrm{lbs}$ initially charged to K Area was assumed to have been sent to Tank 7F. Is it unlikely that coal introduces any significant amounts of organic compounds into the liquid portion of the waste. 


\section{CONCLUSIONS}

Soluble high-level waste from the SRS tank farms potentially contains organic compounds that interfere in the CSSX process. This conclusion is based on records of materials sent to the tank farms and on analytical results from waste samples. However, the concentrations of these compounds are typically low or uncertain so it is not possible to conclude that they will degrade CSSX process performance. Table IX summarizes the compounds identified in this report. Few of these have actually been detected in waste samples. Tributylphosphate was present in a sample from a pump tank but has not been found in samples from waste tanks. Odors emitted through waste tank ventilation systems suggest the presence of trimethylamine (an ion exchange resin fragment). Semivolatile decomposition products of defoaming agents have been found, suggesting non-volatile fragments are likely present. The other compounds listed would not have been detected by the analytical methods used on SRS waste samples.

The presence and use of alkyl-aryl sulfonates (such as found in Alconox ${ }^{\circledR}$ and in Repauno sodium nitrite) are of concern since they are known to interfere in the CSSX process. ${ }^{5}$ Other chemically similar surfactants or emulsifying agents, such as components found in scintillation cocktails currently used at SRS, are also of concern because of their chemical similarity to the alkyl-aryl sulfonates. However, the process includes solvent washing to prevent accumulation and a suppressor (trioctylamine) in the solvent to improve tolerance to these compounds. It is unlikely that these compounds will exist in concentrations higher than those tested and found acceptable. ${ }^{5}$

\section{TABLE IX. Organic Compounds Found in or Sent to the SRS Tank Farms that May Affect CSSX Processing}

\section{Compound}

Tributylphosphate

Siloxanes and siloxanols

Ion exchange resin fragments and trimethylamine

Alkyl-aryl sulfonates

Bis(2-ethylhexyl)hydrogen phosphate

\section{$\underline{\text { Origin }}$}

Solvent used in $\mathrm{F}$ and $\mathrm{H}$ Canyons

Defoaming agents used in DWPF and tank farm evaporators

Ion exchange resins used in canyon process and RBOF

Cleaning agents used in laboratories, decontamination, etc.; anti-clumping agent in sodium nitrite used by DWPF, F and H Canyons, and tank farm inhibited water.

Emulsifying agent used in scintillation cocktails 


\section{FUTURE WORK}

It is recommend that the following additional investigations to improve understanding of the organic compounds in SRS high-level waste.

- Develop analytical methods for non-volatile, potentially interfering compounds and analyze additional samples of liquid wastes from selected tanks in $\mathrm{F}$ and $\mathrm{H}$ Areas.

- Investigate radiolytic and chemical breakdown pathways for high-risk compounds.

- Further investigate the amounts sent to tank farms by review of process records

\section{ACKNOWLEDGEMENTS}

The author gratefully acknowledges the useful discussions and information provided by Seth G. Campbell, Tom Britt, David Hobbs, Tom Peters, Bruce Moyer, and Jeff Gillam during the preparation of this report. 


\section{APPENDIX A. Memorandum "Organic Receipts to the Tank Farms from the F. H, and S Area Canyons" by M. C. H. Fong, 1984}

$\operatorname{CSR} 3-4 \mathrm{~A}$

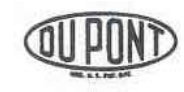

\section{INTER-OFFICE MEMORANDUM}

Savannah River Plant

October 30,1984

TO: $\quad$ P. J. SHIPPY, 703-H

FROM: M. MCHF

ORGANIC RECEIPTS TO THE TANK FARMS

FROM THE $\mathrm{F}, \mathrm{H}$, AND S AREA CANYONS

\section{$\underline{\text { SUMMARY }}$}

This memorandum discusses sources of organics from the $F$ and $H$ Area Separations Process to the waste tank farms and estimates total organic receipts since canyon startup. The estimates show that the expected DWPF S-Canyon annual organics contribution to the H-Area waste tank farm, 2,300 pounds, will represent about $6 \%$ of total receipts in 1989 and about $0.2 \%$ of total estimated inventory.

\section{DISCUSSION}

Both F and H-Area Separations use a solution consisting of $70 \%$ $n$-paraffin and $30 \%$ tributyl-phosphate (TBP) to extract uranium and plutonium from dissolved fuel and target slugs. The majority of this solvent is recovered, but small amounts are lost to the waste stream. The TBP portion of the unrecovered solvent eventually ends up in the tank farm via the canyon evaporator bottoms. The n-paraffin portion is removed in the evaporator overheads.

Based on solvent additions made to the separations process in both areas over the last few years, an estimate can be madt of the annual TBP additions to the tank farms. In F-Area it is estimated that 24,000 pounds per year of TBP is added to the tank farm[1]. In H-Area the estimated addition rate is 2,200 pounds per year.[2] Total inventory in the waste tank farms has been estimated based on these addition rates. The results are presented in Table 1 . 
P. J. Shippy

October 30,1984

Page 2

Both $\mathrm{F}$ and H-Area Separations use a styrene based anion exchange resin in their respective processes. In F-Area, this resin is used in both the Primary Recovery Column (PRC), to recover plutonium and neptunium from unneutralized high activity waste, and in the frames process to decontaminate and separate the plutonium and neptunium recovered on the PRC. A small amount of styrene based cation exchange resin is used in one frame column to absorb and remove thorium. In $\mathrm{H}$-Area the anion exchange resin is used in the frames process to recover plutonium from dissolved neptunium targets.

From 1960 through 1974, Separations used a polystyrene gel-type resin in all the columns (Dowex $1-X 2$ and Dowex 1-X3). The majority of this resin was digested before it was sent to the tank farm as high-heat waste in F-Area and as low-heat waste in H-Area. However, approximately $15 \%$ of the resin was sent to the tank farm undigested due to problems associated with the resin digestion process.

From 1975 to the present, a styrene-divinylbenzene macroporous resin is used in all of the columns (Dowex MSA-1 and Ionac A-641 in the anion exchange columns and Dowex 50W in the F-Area cation exchange column). In F-Area this resin has always been sent to the tank farm undigested. In H-Area the Separations Department stopped digesting the resin in 1982, and shut down the frames process all together in April, 1984. Table 2 lists the type and total amounts of each resin sent to the tank farms since startup of the PRC and frames process for each area. $[3,4]$

Beginning in 1989, the H-Area waste tank farm will receive recycle solution from the DWPF S-Canyon. This solution is estimated to contain about 2,300 pounds of organic material primarily as sodium phenoxide.[5] This represents about a $100 \%$ increase in current annual organic receipts to the H-Area waste tank farm. However, this amount of organic is only $6 \%$ of estimated total receipts (F, H, S-Area) in 1984 and $0.2 \%$ of the total estimated organics inventory received since $F$ and $\mathrm{H}$ canyon startup through 1989.

MCHF : kpg

0008g 
WSRC-TR-2002-00391, Rev. 0

Page 22 of 25

TABLE 1

TOTAL TBP RECEIPTS TO THE TANK FARMS

\begin{tabular}{crr} 
& \multicolumn{1}{c}{ F-AREA } & H-AREA \\
$1954-1955$ & $24,0001 \mathrm{~b}$ & \\
$1955-1959$ & $96,000 \mathrm{~b}$ & $96,000 \mathrm{bb}$ \\
$* 1959-1984$ & $\frac{600,0001 \mathrm{~b}}{55,0001 \mathrm{~b}}$ & \\
Tota1 & $720,0001 \mathrm{~b}$ & $151,0001 \mathrm{~b}$
\end{tabular}

*H-Area switched from the Purex to the HM Process in 1959 .

TABLE 2

TOTAL ORGANIC RESIN RECEIPTS TO THE TANK FARMS

\begin{tabular}{lrrr} 
& \multicolumn{1}{c}{ F-AREA } & & H-AREA \\
$\begin{array}{l}\text { Polystyrene Gel-Type Resin: } \\
\text { Total }\end{array}$ & $18,000 \mathrm{lb}$ & $26,000 \mathrm{lb}$ \\
$\quad$ Undigested & $3,000 \mathrm{lb}$ & $4,000 \mathrm{lb}$ \\
$\begin{array}{l}\text { Styrene-Divinylbenzene } \\
\begin{array}{l}\text { Macroporous Resin: } \\
\quad \text { Total }\end{array}\end{array}$ & & & \\
$\quad$ Undigested & $25,000 \mathrm{lb}$ & 55,000 & $1 \mathrm{~b}$ \\
& $25,000 \mathrm{lb}$ & $13,000 \mathrm{lb}$
\end{tabular}

References

[1] Telephone conversation between N. R. Davis and T. C. Campbell on $10 / 21 / 83$.

[2] Telephone conversation between N. R. Davis and M. L. Cowen on $10 / 31 / 83$.

[3] Memo from K. S. Fuller to M. C. Healy, Undigested Resin to Waste Storage From Pu-238 Frames Process, Feb. 7, 1984.

[4] Memo from D. M. Cooper to M. C. Healy, Resin Usage in 221-F Canyon, Feb. 14, 1984.

[5] Presentation to the DWPF/WM Interfaze Committee, "Organics Recycled to the Tank Farm", I. D. Goren, 10/25/84. 


\section{REFERENCES}

${ }^{1}$ J. R. Hester, "High Level Waste Characterization System (WCS)," WSRC-TR-96-0264, Rev. 0, December, 1996.

${ }^{2}$ Record of Decision, Federal Register, Vol. 66, No. 201, pp. 52752-52756, October 17, 2001.

${ }^{3}$ J. A. Campbell, L. R,. Greenwood, O. T. Farmer III, and E. W. Hoppe, "Technical Task Plan RL31WT21 Subtask C, Organic and Actinide Characterization," PNNL-TP-43707001, Rev. 1, March 26, 2002.

${ }^{4}$ B. A. Moyer, S. D. Alexandratos, P. V. Bonnesen, G. M. Brown, J. E. Caton, Jr, L. H. Delmau, C. R. Duchemin, T. J. Haverlock, T. G. Levitskaia, M.P. Maskarinec, F. V. Sloop, Jr., and C. L. Stine, "Caustic-Sid Solvent Extraction Chemical and Physical Properties Progress in FY 2000 and FY 2001," ORNL/TM-2001/285, February 2002.

${ }^{5}$ L. H. Delmau, G. J. Van Berkel, P. V. Bonnesen, and B. A. Moyer, "Improved Performance of the Alkaline-Side CSEX Process for Cesium Extraction from Alkaline High-Level Waste Obtained by Characterization of the Effect of Surfactant Impurities," ORNL/TM-1999/209, October 1999.

${ }^{6}$ L. H. Delmau, T. J. Haverlock, and Bruce A. Moyer, "Caustic-Sid Solvent Extraction: Anti-Caking Surfactants Found to Be Cause of Apparent Effect of High Nitrite Concentration on Cesium Stripping," ORNL/TM-2002/104, May 2002.

${ }^{7}$ M. Layton, "Contribution of Organics to the Tank Farm Deflagrations," NI-HLW-98007, Rev. 3, July 27, 1999.

8 a. R. F. Swingle, II, "Report on Analyses of Tank 21H and 23H Samples," WSRC-TR98-00398, Rev. 0, November 12, 1998.

b. R. F. Swingle, II, J. E. Young, T. A. Nance, Z. H. Qureshi, and S. L. Crump, "Analysis of Organic Samples from the 5-H and 3-F Pump Tanks and Waste Tank 38H," WSRC-TR-99-00188, Rev. 0, June 1, 1999.

c. R. F. Swingle, II, and T. L. White, "Contribution of Ammonia and Defoamers to Lower Flammability Limit in SRS High Level Waste Tanks," WSRC-TR-99-00189, d. R. F. Swingle, II, "Analysis of Organic Samples from Waste Tanks 26ZF, 33F, 46F, and 43H - Summer 1999," WSRC-TR-99-00397, Rev. 0, October 20, 1999.

e. R. F. Swingle, II, "Analysis of Floating Organic Samples from Waste Tanks 26F and 33F - Fall 1999," WSRC-TR-2000-00007, Rev. 0, February 9, 2000.

f. R. F. Swingle, II, "Analysis of December 199 Samples from Pump Tank 3F for Organics," WSRC-TR-2000-00063, Rev. 0, March 21, 2000.

g. R. F. Swingle, II, J. E. Young, and S. L. Crump, "Analysis of Vapor Samples from the Organic PISA High Level Waste Tanks," WSRC-TR-2000-00090, Rev. 0, March 21, 2000 . 
h. Thomas E. Britt, "Tank 39 and H Pump Tank-6 Acceptance of Canyon Waste," WSRC-TR-2000-00091, Rev. 0, April 24, 2000.

${ }^{9}$ R. A. Pierce, "TBP Steam Stripping," SRT-CHT-99-2009, Rev. 0, June 16, 1999.

${ }^{10}$ Westinghouse Savannah River Company, "Liquid Radioactive Waste Handling Facilities Safety Analysis Report," WSRC-SA-33, Rev. 3, September 1999.

${ }^{11}$ a. T. L. Davis, D. W. Tharin, and D. R. Lohr, "History of Waste Tank 15, 1959 through 1974," DPSPU 77-11-126, June 1978.

b. C. J. Thomas and R. Robnett, "History of Waste Tank 6, 1954 through 1974," DPSPU 81-11-4, March 1981.

12 C. S. Boley, "Estimation of Canyon Historical Solvent Losses to Tank Farms," HLWSTE-98-0318, October 29, 1998.

13 S. W. Claybrook and S. A. Wood, "Organic Evaporation in Waste Tank C-103," WHC-SD-WM-ER-344, Rev. 0, June 1994.

14 W. W. Schulz, J. D. Navratil, and A. Talbot, editors, Science and Technology of Tributyl Phosphate, Volume 1 - Synthesis, Properties, Reactions, and Analysis, CRC Press, Inc. Boca Raton, Florida, 1984.

15 a. M. D. Snyder, "Dissolution of Ion Exchange Resins in Alkaline Permanganate," DP717, July 1962.

b. M. E. Jamison, "Implications of Organic Constituents and Ammonia on Tank Farm Flammability Controls (U)," WSRC-TR-98-00014, Rev. 1, April 27, 1998.

16 M. G. Bronikowski, "Tank 42H and Tank 51H Exhaust Vent Sampling Results for TMA (U)," WSRC-TR-99-00439, Rev. 0, November 15, 1999.

${ }^{17}$ J. W. T. Spinks and R. J. Woods, An Introduction to Radiation Chemistry, 3rd edition, John Wiley and Sons, New York, 1990.

18 H. J. Groh, "Removal of Silica from Solutions from Nuclear Fuels, DP-293, June 1958.

19 J. T. Baker,Inc., Material Safety Data Sheet for Alconox ${ }^{\circledR}$, March 2, 1994.

${ }^{20}$ Packard Instruments, Material Safety Data Sheet for Ultima Gold ${ }^{\mathrm{TM}}$, April 1, 2001.

${ }^{21}$ R. A. Adams, D. P. Lambert, R. C. Fowler, T. B. Peters, G. C. Winship, M. R. Norton, N. P. Malik, and R. J. Bentley, "HLW Tank 48H Disposition Alternatives Identification Phase 1 \& 2 Summary Report," WSRC-RP-2002-00154, Rev. 1, July 15, 2002. 
22 C. D. Banaszewski, "Final Report on Phenylborate Decomposition in Tank 49H," WSRC-TR-2001-00339, Rev. 1, August 23, 2001.

23 J. M. Gillam, "Waste Compliance Plan for Pre-Radioactive Liquid Waste Transfers from DWPF to 241-H Tank Farm," WSRC-RP-95-673, Rev. 0, July 3, 1995.

24 P. M. Patel, "Procurement Specification for LWF Sodium Titanate Slurry (U)," Specification No. X-SPP-S-00009, Rev. 0, March 26, 1995.

25 J. R. Fowler, "Chemical and Radiochemical Analyses of SRP Liquid Waste," DPST80-409, July 1980. 